\title{
РОЛЬ СЕРЕДНЬОГО МЕДИЧНОГО ПЕРСОНАЛУ В СИСТЕМІ ОХОРОНИ ЗДОРОВ'Я НА СУЧАСНОМУ ЕТАПІ
}

\author{
А. Ю. Байцим, Д. Р. Тугаров, І. Я. Криницька \\ Ковельське діагностичне відділення центральної міської лікарні \\ Кременецьке медичне училище імені Арсена Річинського \\ ДВНЗ «Тернопільський державний медичний університет \\ імені I. Я. Горбачевського МОЗ України»
}

У статті викладено сучасні дані щодо професійних та етичних якостей медичної сестри, реформи медсестринства на сучасному етапі та нових компетенпій в роботі середњњого меднчного персоналу.

\section{ROLE OF NURSING STAFF IN THE HEALTH SYSTEM AT THE PRESENT STAGE}

\author{
A. Yu. Baytsym, D. R. Tuharov, I. Ya. Krynytska \\ Kovel Diagnostic Department of the Central City Hospital \\ Kremenets Medical School by A. Richynskyi \\ SHEI «Ternopil State Medical University by I. Ya. Horbachevsky of MPH of Ukraine»
}

The article presents current data on professional and ethical qualities of a nurse, nursing reform at the present stage and new competencies in the nursing staff work.

Вступ. Кожна професія висуває певні вимоги до людини, але, мабуть, тільки праця медика накладає настільки високі та специфічні обов'язки на фахівця, передбачає високу відповідальність за надану ним допомогу пацієнтам. Медичним працівникам люди довіряють найдорожче - здоров'я і життя, своє і своїх близьких, і тому очікують від них повної самовіддачі. образ медичного працівника почав формуватися ще в глибоку давнину і вирішальний вплив на це зробили праці видатного лікаря древньої Еллади Гіппократа, який вважав, що «особа, яка присвятила себе медицині, має володіти такими якостями: безкорисливістю, скромністю, цнотливістю, здоровим глуздом, холоднокровністю...» [1]. У давні часи лікар не займався цілительською діяльністю на самоті: у нього завжди були помічники, які в більш пізній період (десь у VIII ст.) сформувалися в когорту сестер милосердя. Основоположник наукової сестринської справи Флоренс Найтінгейль (1820-1910) в книзі «як потрібно доглядати за хворими»: писала про те, що головне мистецтво доглядальниці полягає в умінні відразу відгадувати бажання хворого, не чекаючи поки він їх висловить [1]. Флоренс Найтінгейль надзвичайно

๑) А. Ю. Байцим, Д. Р. Тугаров, І. Я. Криницька, 2015 освічена на той час жінка у 1860 р. відкрила школу, яка не підпорядковувалась лікарні, а була автономним світським навчальним закладом. Підготовка медичних сестер складалася з однорічного навчання і двохтрьохрічного практикування в госпіталях. Реформа Флоренс Найтінгейль привела до того, що професію медичної сестри визнали у суспільстві. Саме цю дату ВООз (1860) вважає днем народження нової професії - медичної сестри. Як будь-який вид професійної діяльності, робота медичної сестри стала набувати специфічних рис, які поступово все більше відрізняли її від функцій суто «помічника лікаря». Зокрема, у США в 1973 р. з'явилося поняття «сестринський діагноз», під яким розуміли оцінку ставлення хворого до свого стану, здоров'я, хвороби (уточнимо: лікарський діагноз спрямований на виявлення порушень у здоров'ї, відхилень їх від норми) [4].

Основна частина. Етичною основою професійної діяльності медичної сестри є гуманність і милосердя. Приймаючи і розділяючи загальнолюдські й загальномедичні етичні цінності, професійний корпус медичних сестер декларує унікальність своєї професії та особливий характер етичних взаємин з колегами і пацієнтами. Найважливішими завданнями професійної 
діяльності медичної сестри є: комплексний всебічний догляд за пацієнтами і полегшення їхніх страждань; збереження здоров'я і реабілітація; сприяння зміцненню здоров'я та профілактика захворювань [6].

у Кодексі професійної етики медичних сестер висуваються такі вимоги до особистості медичної сестри: моральні якості (милосердя, доброзичливість, чуйність, терпіння, уважність, самовідданість, бездоганна чесність, працьовитість, старанність, ввічливість, почуття власної гідності, відповідальність за доручену роботу); етичні якості (охайність, акуратність, бездоганний зовнішній вигляд, відсутність шкідливих звичок); інтелектуальні якості (ерудованість, спостережливість, ініціатива, логічність мислення, прагнення до самовдосконалення і осмислення в роботі) [7].

Основоположними принципами світової концепції сестринської справи на сучасному етапі можна вважати такі [5]:

1) лікарська і сестринська справа - взаємопов'язані, доповнюючі один одного процеси, що становлять дві самостійні професії - лікарська справа (вивчає патологічні процеси, хвороби, що розвиваються на їх фоні, способи впливу на ці патологічні процеси) і сестринська справа (вивчає реакцію індивідуума на хворобу);

2) в основі тієї чи іншої професії повинні лежати загальні фундаментальні знання, а повноцінна фундаментальна діяльність повинна включати три взаємозалежних складових - філософію, теорію і практику;

3) сестринська справа як молода професія, заснована лише на практиці, поступово освоює нову філософію, розвиваючись як професія. При цьому формується інша психологія медичної сестри, яка виконує роль фахівця - партнера лікаря і пацієнта, здатного до самостійної роботи в рамках єдиної лікувальної бригади і яка в основу своєї професійної діяльності ставить особистість пацієнта. Сестринська справа існує і розвивається як унікальна форма гуманітарної допомоги, заснована на всебічній підтримці з боку суспільства;

4) медична сестра несе юридичну відповідальність за свою професійну діяльність, яка регламентується відповідними правовими актами;

5) в основі сестринської допомоги лежить таке поняття, як сестринський процес, який складається 3 ряду етапів - сестринського обстеження, виявлення проблем пацієнта (з формулюванням сестринського діагнозу), планування та реалізації сестринського втручання, оцінки його ефективності.
Медичні сестри - це найбільший загін фахівців охорони здоров'я будь-якої країни. У Європі працює більше 5 млн медсестер, з них близько 330 тис. в Україні [3]. Згідно з сучасною концепцією розвитку сестринської справи медична сестра повинна бути висококваліфікованим фахівцем - партнером лікаря і пацієнта, здатним до самостійної роботи у складі єдиної команди. На сучасному етапі системі охорони здоров'я потрібна не просто медична сестра, а професіонал своєї справи. Реформа медсестринства передбачає підготовку фахівця нового типу. Медсестра повинна володіти клінічним мисленням, уміти орієнтуватися в характері патологічних змін в організмі, правильно вибрати тактику при наданні екстреної медичної долікарської допомоги, досконало володіти технікою сестринських маніпуляцій, вміти скласти плани сестринського догляду за пацієнтом і диспансерного спостереження за ним, пропагувати здоровий спосіб життя [8].

Значне зростання витрат на медицину зумовлює вимоги до економічної ефективності всіх видів медичної діяльності, раціонального використання ресурсів. Перебудова і інтенсифікація діяльності всіх учасників лікувально-діагностичного процесу в цих умовах неминуча. Розширення та якісна зміна системи медичної допомоги збільшують обсяги навантаження і впливають на характер діяльності кваліфікованого середнього медичного персоналу, від якого залежить якість і умови догляду за пацієнтами, ефективність лікування та реабілітації.

Проте в нашій країні протягом багатьох років відбувалася недооцінка сестринської справи, що призвело до відставання у цій галузі охорони здоров'я і стало причиною погіршення якості не тільки сестринської, але і медичної допомоги в цілому. Утворений розрив між розвитком медицини і організацією сестринської допомогиє істотним гальмом у реалізації сучасних медичних технологій, поліпшенні результатів медичної діяльності, знижує ефективність всіх організаційних та лікувально-діагностичних заходів. У цих умовах недостатньо лише професійної компетенції медсестри. Необхідно активно впроваджувати принципи менеджменту та маркетингу вії діяльність, включаючи знання управління персоналом, різних лікарських препаратів і виробів медичного призначення, структури витрат і механізмів ціноутворення на ті чи інші медичні послуги та ін. Тому постійно підвищуються вимоги до особистості медичних сестер (особливо 
старшої та головної медсестер), їх загальної та спеціальної ерудиції, навичок управлінської діяльності [10]. На сучасному рівні розвитку сестринської справи від медичної сестри потрібне вміння самостійно оцінювати стан і потреби хворого, вести правильне спостереження за ним, приймати обґрунтовані рішення, пов'язані з певною відповідальністю, коли від професійної компетенції залежить успіх лікування [11, 12]. Перехід на нові принципи сестринської роботи вимагає розробки нормативно-законодавчої бази, що визначає галузь професійної компетенції та включає нові переліки посадових обов'язків, нові навчальнометодичні матеріали, нові стандарти сестринської роботи. Тим часом досі відсутній закон, який регламентує діяльність медичної сестри, перелік її прав і обов'язків і соціальний статус.

Однією з тенденцій світової охорони здоров'я $\epsilon$ підвищення ролі сестринського персоналу з різним рівнем підготовки і, зокрема, широке використання сестринських кадрів в управлінні [9].

Передумовами розширення і виникнення нових ролей сестринського персоналу є: старіння населення; поширеність хронічних захворювань; підвищення очікувань від медичної допомоги (вимоги комфорту, зручності, стислих термінів, особливо на дому); зміна цінностей та етичних норм (автономія пацієнта, його максимальна участь в процесі лікування, у прийнятті рішень, у здійсненні самодогляду); економічні обмеження (висока вартість стаціонарного лікування один із стимулів до розвитку сестринських служб патронажна дому, консультації, індивідуальне «ведення» пацієнтів із хронічними захворюваннями).

\section{ЛITEPATУРА}

1. Баршай Т. И. Образ идеальной медицинской сестры у выпускников медучилища и медсестер [Электронный ресурс]\Т. И. Баршай. - Режим доступу: http://media.miu. by/files/store/items/uses/xvii/mim_uses_xvii_34004.pdf.

2. Батман Ю. А. Медицинская сестра неонатальных отделений г. Донецка - какая она есть? / Ю. А. Батман, Г. Л. Линчевский, О. В. Швыдкий // Неонатологія, хірургія та перинатальна медицина. - 2011. - Т. 1, № 1. - С. 30-33.

3. Васильєва Н. А. Організація роботи медперсоналу під час епідемії грипу та профілактичні заходи / Н. А. Васильєва, Л. М. Зубкович// Медсестринство, - 2010. - № 4. - C. 22-24.

4. Вахитов Ш. М. Роль медицинских сестер в современном здравоохранении / Ш. М. Вахитов, Э. И. Нуриева // Казанский медицинский журнал. - 2010. - Т. 91, № 2. C. 260-263. у 1997 р. за підтримки Міністерства охорони здоров'я України була створена Асоціація медичних сестер України, в першорядні завдання якої були внесені: організація безперервного навчання через систему підвищення кваліфікації та післядипломної освіти, удосконалення подальшої медсестринської освіти, розробка стандартів професійної діяльності, впровадження системи контролю якості медичних послуг. Наступною спробою реформування медсестринства в рамках міжнародного процесу підготовки медичних сестер, у тому числі і з вищою освітою, був наказ МОз України № 585 від 08.11.2005 р. «Програма розвитку медсестринства України на 2005-2010 рр.».

Важливим $є$ створення стандартів професійної діяльності та розробка рекомендацій щодо встановлення диференційованого навантаження на сестринський персонал та атестації робочих місць. Природно, що реалізація всіх цих планіві рекомендацій можлива тільки за умови розробки методики оплати роботи медичних сестер залежно від якості й обсягу сестринських втручань на основі нових технологій сестринської допомоги [2].

Висновок. Соціально-економічні та соціально-психологічні зміни в суспільстві, розвиток нових технологій в охороні здоров'я, високі вимоги до якості діяльності медичної сестри привели до необхідності вдосконалення сестринської справи, включно підготовку висококваліфікованих кадрів та їх раціональне використання. Без докорінного перегляду всієї програми підготовки та перепідготовки фахівців сестринської справи, без впровадження нових технологій організації сестринської допомоги, матеріальної та правової підтримки медичних сестер подальше вдосконалення системи охорони здоров'я просто не можливо.

5. Веткина О. А. Пути оптимизации деятельности среднего медицинского персонала отделений лучевой диагностики в современных условиях : дисс. ... канд. мед. наук / О. А. Веткина. - СПб., 2009, - 171 с.

6. Иванюшкин А. Я. Этический кодекс медицинской сестры России / А. Я. Иванюшкин, В. В. Самойленко. СПб., 2010. - 22 с.

7. Кодекс профессиональной этики медицинских сестер Республики Беларусь [Электронный ресурс]. - Режим доступу : (http://www.belooms.org/index.php?area=1\&p= static\&page $=$ kodeks)

8. Кузмінська І. В. Медсестринство як впливова самостійна ланка медицини /.. В. Кузмінська, І. М. Круковська // Медсестринство. - 2009. - № 2. - С. 28-30.

9. Сестринский персонал медицинских организаций в условиях реформирования здравоохранения / 
Е. П. Жаворонков, Ю. О. Ким, Т. Г. Николаева, Н. В. Куликова II Медицина и образование в Сибири. - 2012. - № 4.

10. Hassmiller S. Nursing's role in healthcare reform / S. Hassmiller // American Nurse Today. - 2010. - Vol. 5, № 9. - P. 68-69.

11. Patterson E. Primary health care and general practice nurses: what is the nexus? / E. Patterson, K. Price, D. Hegney //
Australian Journal of Primary Health. - 2005. - Vol.11 (1). - P. 9.

12. Browne G. Better care: An analysis of nursing and healthcare system outcomes / G. Browne, S. Birch, L. Thabane // Canadian Health Services Research Foundation. 2012 Режим доступу: http://archives.enap.ca/ bibliotheques/2013/06/030429355.pdf

Отримано 22.10.15 